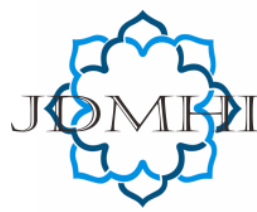

email: jdmhi@walisongo.ac.id

Journal of Digital Marketing and Halal Industry

ISSN: 2716-4810 (print) ISSN: 2716-4802 (online)

\title{
Halal Food Industry: Challenges And Opportunities In Europe
}

\author{
Nur Aini Fitriya Ardiani Aniqoh ${ }^{1}$, Metta Renatie Hanastiana ${ }^{2}$ \\ ${ }^{1}$ Faculty of Economics and Islamic Business, Universitas Islam Negeri Walisongo, Semarang \\ ${ }^{2}$ Faculty of Economics and Business, Universitas Gadjah Mada, Yogyakarta
}

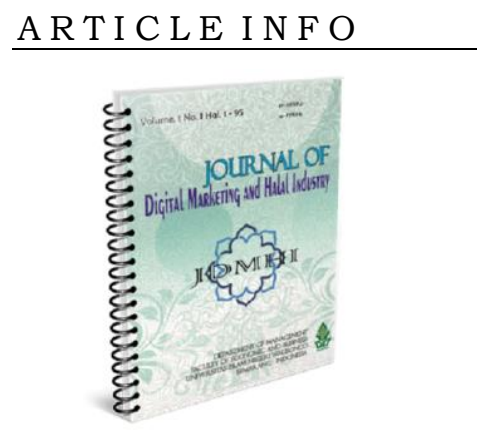

Article history:

Received 16 June 2020

Accepted 04 July 2020

Published 10 July 2020

Keywords:

European Industry, Halal Food

Industry

\section{A B S T R A C T}

Halal industry in Europe has experienced significant development, especially in the food sector. This study aims to analyze the challenges and opportunities of the halal food industry in Europe. The method uses a qualitative approach, with secondary data sources. The analysis technique uses a descriptive approach. The study results show that the development of the halal food industry in Europe was triggered by the increasing demand for halal certification and quality assurance, as well as the development of the tourism sector. This is a great opportunity for industry players to be able to meet the high demand for halal food. The challenge is how to improve quality and can meet halal standards to meet global demand.

@2020 Journal of Digital Marketing and Halal Industry

\section{Introduction}

The Muslim world shows rapid population growth, dynamic economic development, and income also continues increased. Such conditions can encourage increased consumption globally, especially consumption of halal products. Global halal market currently able to absorb around $16.7 \%$ of the entire global food industry. Driven by increasing demand, the halal food market continues building momentum throughout the global food supply chain. According to Thomson Reuter and Dinar Standard (2015), in 2014 alone it is estimated that global Muslim spending on food and drinks ( $F \& B$ ) increased $4.3 \%$ to reach $\$ 1.128$ billion. This condition makes the potential of the halal food market reaches $16.7 \%$ of global spending

\footnotetext{
* Corresponding author. email: nurainifaa@walisongo.ac.id DOI: http://dx.doi.org/10.21580/jdmhi.2020.2.1.5799
} 
2014 (Standard, 2015).

Referring to pewforum (2016), 3 that Muslim population in the European region in 2030 is projected to be more than $10 \%$ of the population in the following countries namely Kosovo (93.5\%), Albania (83.2\%), BosniaHerzegovina (42.7\%), Republic of Macedonia (40.3\%), Montenegro (21.5\%), Bulgaria (15.7\%), Russia (14.4\%), Georgia (11.5\%), France (10.3\%) and Belgium (10.2\%). Of these countries, by 2030 Russia is projected to have the largest Muslim population in Europe, where the Muslim population is expected to reach 18.6 million, an increase from 16.4 million Muslims in 2010. Muslim growth rates in Russia are projected to reach $0,6 \%$ per year. While the number of non-Muslims also decreased by $0.6 \%$ per year during the period (Pewforum, 2016).

Based on the data above, the halal food industry in Europe is growing rapidly. Finding halal food for Muslims in Europe has become easier. In every place like in the Netherlands, France, Germany, or Belgium there are always Döner kebab outlets, or restaurants that sometimes have halal certificates. Halal stores exist in several cities in Europe. In ordinary supermarkets many halal products have been produced, such as in Germany or the Netherlands. However, some do not include the halal logo but are stated on the company's website, or can ask directly to the company's customer service. Application to check halal food based on barcode is also available. In Germany, France, the Netherlands and Belgium, the market for halal products is increasing so that many producers benefit in the halal industry market.

\section{Literature Review}

\section{Definition of Halal}

Halal means justified. His opponent is forbidden to mean prohibited, or not justified according to Islamic law (Fauzi et al., 2020). While thoyyib means quality and does not endanger health. In Islamic teachings, all types of food and drinks are basically halal, except for only a few that are forbidden. That is forbidden becomes lawful when in an emergency. Conversely, halal can be haram if consumed beyond the limit (Rohman A, 2012).

Halal is a term from the Arabic language which means permissible, legal, and according to Islamic or sharia law. If associated with pharmaceutical products, food, and drinks, halal can be interpreted as pharmaceutical products, food or drinks which is allowed to be consumed by a Muslim (Rohman A, 2012).

Consuming halal products is obligatory for Muslims as described in the Qur'an surah AlMaidah paragraph 88 as follows:

"And eat halal food again which is good from what Allah has sustained and fear Allah that you have faith in Him. " Al-Maidah verse 88

And explained in surah Al-Baqarah verse 168 which is as follows:

"O people, eat halal better than there is on earth, and do not follow the steps of Satan; because really Satan is a real enemy to you. " Al-Baqarah verse 168

In the hadith, the Prophet Muhammad said: "Indeed, Allah is good, does not accept except the good". The term "halal" is also often followed by the term "Thayyib" which means products that are good for consumption, 
quality, holy, safe, harmless or health and has been mentioned in surah Al-Baqarah Verse 172 as follows:

"O you who believe, eat among the good fortune that is We give it to you and give thanks to God, if it is truly to- You worship. " Al-Baqarah Verse 172

The concept of Halal is not only related to to cosmetics, personal care, pharmaceuticals but also halal food industry. Because this is mostly produced by non-Muslim producers (Waqar Ahmed, 2018), there are concerns among consumers about the halal of their ingredients because it is important to determine the halal product. For example, the involvement of meat and alcohol extracted by enzymes as preservatives creates a lot of suspicion among Muslim consumers (Mukhtar, 2012).

Therefore, understanding halal and haram is actually not only related to the problem of food and drinks, but also concerning the action. So there are actions that are permitted and forbidden.

In research (Waqar Ahmed, 2018) that the Halal process, most consumers are more interested in buying halal food and products that are certified with the "halal" logo. The results of this study also show that except for consumer behavior attitudes, all other significant factors are studied. Thus, there is a very significant relationship between consumers' willingness to pay for Halal products and the demand for halal certification of food and other products.

Basically, Halal is a term that is usually used by Muslims and non-Muslims; that is an entity, good, service or procedure that is permissible in Islam. This is not only limited to food or ingredients but requires whole the process (Haleem, 2017). HDC Halal Development
Corporation 2010 Highlights that Halal products must be made in accordance with Islamic Sharia, including all logistics activities

\section{Halal Food}

The definition of halal food and drink includes (Haleem, 2017) substance is Halal, halal how to process it, halal how to get it, and, non-halal drinks.

1. Halal food substances

Allah is most gracious, most gracious. Too much, even almost all types of food are halal and can be consumed. Conversely too few types of prohibited foods that should not be consumed. The wisdom of the ban is clearly Allah who knows. The goodness of the existence of the prohibition is clearly for the benefit and goodness of humanity itself. Among other things, as a testament to spiritual obedience through food and drink and so people know / want to be grateful. Carcasses, blood and swine are strictly forbidden by Allah, according to the above verse. Furthermore, all animals that die do not go through the process of slaughtering haraam, equated with the carcass. Including animals that die while transporting for only a short time, they cannot be slaughtered and consumed by humans.

2. Halal food according to the way the process

Halal food but if it is processed in a nonhalal way, it becomes unclean. Unlawful processing if done:

Animal slaughter that is not done by a Muslim, by not mentioning in the name of Allah and using a sharp knife.

Slaughter of animals that are clearly designated or offered to idols (offerings). 
Because the blood is forbidden, then in slaughter, the blood of the slaughtered animal must come out completely, and the loose veins and respiratory tract must be broken and must be done politely, using a sharp knife.

Halal animal flesh is contaminated by illicit substances or is not halal to be halal. The definition of polluted here can be through mixing with non-halal materials, in the form of raw materials, herbs or other supporting materials. It could also be because there are no separate places and equipment used to process non-halal materials.

The fish both living in fresh water and those that live in sea water are all halal, even without slaughter, including all types of animals that live in water.

In addition to the above, there are several types of animals that are prohibited by the opinions of scholars, but the basis is still inviting differences of opinion.

3. Halal how to get it

A devout Muslim is very concerned about the food he consumes. Islam provides guidance so that Muslims only eat and drink halal and thoyyib, meaning that food is spiritually healthy and hygienic. Consuming food that is obtained in a way that is not halal means that it is not spiritually halal will negatively affect one's spiritual life. The blood that flows in his body becomes frightening, it is difficult to get calm, his life becomes violent, he never knows satisfaction, he never knows gratitude, his worship and prayers are hard to accept by God.

4. Non-halal drinks
All types of intoxicating drinks are haram. This includes drinks that are contaminated with intoxicants or non-halal ingredients. Which is widely circulated now in the form of alcoholic drinks.

The habit of getting drunk by drinking liquor apparently has been around for a long time and has become a habit by almost all nations of the world. During the time of the prophet Muhammad SAW, the Arab community also had this custom. The Prophet gradually eradicated this bad habit.

First, forbid people from praying while still drunk (QS 4:34). Next states that khamar or liquor is a sin or an ugliness greater than the benefits or goodness (QS 2: 219). Finally, the new prohibition explicitly states that liquor is a heinous act, as an act of the devil, because it is really shunned (QS 5:90)

Therefore, halal products refer to products that meet Shariah requirements prevent blackness, both in terms of the substance and other than the substance(Burhanudin, 2011). According to (Al-Ghazali, 2007), which results in food (objects) can become illegitimate because of its unclean types, such as khamar, pig, and so on, including in it products of its derivatives (alcohol, gelatin, etc.), and because it is unclean how to obtain it included in the assets to obtain it and the process of making it.

\section{Method, Data, and Analysis}

The method used in this study is a qualitative descriptive method. Qualitative descriptive refers to the identification of the distinguishing traits or characteristics of a group of people, objects, and events. Basically, 
descriptive qualitative. involves the conceptualization process and results in the formation of classification schemes. In addition to describing the characteristics of a symptom or problem under study, this study also focuses on the basic 'how' questions by trying to obtain and convey facts clearly, thoroughly, and completely without many unnecessary details (Silalahi, 2010).

The data used are secondary data sourced from publications namely books, journals, newspapers, websites, and policy documents relating to the issues discussed.

In running this research, the researcher tends to use descriptive study. Through descriptive study, the researcher tries to discover answers to the question who, what, when, where, and, sometimes, how (Bolwijn et al., 2018). Descriptive studies are also called observational, because you observe the subjects without otherwise intervening (Silalahi, 2010). A fundamental element of descriptive reporting is a clear, specific, and measurable definition of the condition in question (Silalahi, 2010).

\section{Result and Discussion}

Halal food industry in Europe is developing quite rapidly and significantly, Europe is starting to realize the potential of the halal industry which can improve its economy.

According to (Standard, 2015), the priority of Muslim consumers when traveling is Halal product availability $(66.8 \%)$. The numbers also indicate that the product Halal becomes a basic requirement and making it available is a basic requirement for won the hearts of the Islamic market (Standard, 2015). Halal products no longer to the attention of Muslim entrepreneurs and consumers, but nonMuslim producers too interested in participating in providing halal products because of them market needs and demands(A, 2016), and of course it is very important to practitioner business. (Nur Asnawi, 2018). Investigate consumer decisions on halal products, i.e. First, considering the size of the halal food market and its evolution and. Second, considering relevance this problem policy. The growing Halal popularity can be attributed to religious spirit and also the belief that it is cleaner, healthier and tastier (Suddin Lada, 2009).

Halal food and beverages in the European region has been segmented as per geography into major countries such as Spain, United Kingdom, France, Russia and Italy and other European countries. The UAE, Malaysia and Indonesia are the largest export market for Europe's halal-certified food products. In the continent, the biggest consumers in Europe are France and the UK.

HFCE (European Halal Food Council) has certified more than 400 European food companies. This is expected to increase the growth of the halal food industry in Europe. The food industry in Europe is starting to see the potential for halal food as promising. International food companies such as Nestlé or Unilever have for years offered a variety of halal products in various Muslim countries in the world. So food entrepreneurs in Europe, such as the German sausage company Meemken, make various types of sausages in accordance with Islamic rules. Every week, the company sends nearly 100 tons of salami, fried sausages, and other sausages to food vendors in Germany and outside Germany. European countries, with a high Muslim population, have fully adjusted to the desires of 
consumers. In France, Casino supermarkets have offered meat and sausages according to halal food provisions and in the UK halal food has been offered at Tesco and Sainsbury supermarkets. British drugstore, Boots sells baby food produced according to Islamic teachings. And because it managed to make a big profit in London, McDonalds will soon be offering halal chicken in other European countries. This shows that the opportunity for the halal market in Europe is growing.

\section{The Opportunity of Halal Food Industry}

The market for halal food products in Muslim minority countries is also supported by the growth of the Muslim population. The world's Muslim population is estimated to reach 1.6 billion people in 2010 or 23 percent of the world's population, most still in Asia Pacific, then the Middle East, Sub-Saharan Africa, Europe to North and Latin America. The population is expected to increase to 29 percent of the world population until 2050 ("Halal La Carte," 2020).

PEW research reveals that more than 20 percent of the world's Muslim population lives in Muslim minority countries, especially in Western countries. Political upheaval and ethnic clashes in several Muslim countries also resulted in Muslim migration to Western countries, thereby increasing the population in Muslim minority countries (Pewforum, 2016).

In Europe, the Muslim population is expected to grow by 33 percent over the next 20 years, increasing from 44 million to 58 million by 2030. Europe is the fourth largest Muslim population area in the world, reaching 43 million (2010). Demand for halal products on the European market has also increased by an average of 15 percent per year since 2003 .
Muslims in European countries are generally a minority, including in France (Euromonitor, 2015).

Most European entrepreneurs see great opportunities in the halal food industry, more Muslim population in Europe is increasing. European Muslim communities adhere to the teachings of Islam in consuming halal food. They don't eat pork and drink alcohol, they only buy food that is guaranteed with the halal label. Basically, they are also more comfortable applying sharia principles in their daily lives.

In Islam, The Qur'an has agreed specifically to matters issued. In this context besides food must be "halal", it must also be "tayyib", which means "good." An example is during the process of slaughtering animals that must be done according to Islamic religious rules. The Muslim community in Europe is very concerned about the problem, so they will buy food with a halal label. In addition, several supermarkets in Europe have also given a Halal label on some of the products they sell.(Juan Eduardo Campo, 2009)

There is a great opportunity for European Muslims to position themselves favorably. Globally, more than 2.1 billion Muslims have the potential to network in the halal market, and they represent enormous spending power and economic potential. There are six countries or regions (around Europe) that are predominantly Muslim, namely Turkey, Azerbaijan, Kazakhstan, Albania, Bosnia and Kosovo. However, if viewed from the number, although not the majority, Germany actually has the largest Muslim population, then France, followed by Britain. These countries are filled with Muslim immigrants. So that this is a great opportunity for several Muslim countries like Indonesia to be able to develop 
the halal food industry in Europe. An example is that PT Sentra Food Indonesia Tbk (SFI) plans to start exploring exports to the European market this year because the European market is considered quite potential for the company's business (Lembaga Pengkajian Pangan, Obat-obatan, 2016).

This food and beverage sector has great potential in the halal industry. Today's society is increasingly concerned with the halal food and drinks they buy. A publication by Geo Population in the Ministry of Trade's report that the Muslim population in France in 2011 reached 4.7 million people or 7.5 percent of the total population of the secular state. In France, within a period of 4 years, the average growth of the Muslim population reached 1.125 percent per year. So in France, the meat market has the highest demand among other halal foods. This is related to the law in Islam which does have provisions in slaughtering animals. Research conducted by Florence Bergeaud Blackler and Karijn Bonne, found that people consume halal food in France because the taste of halal meat and chicken is considered better. Even so, Florence and Karijn found that the main reason people buy halal products is because of religious orders (Bonne, K., and Verbeke, 2018).

\section{The Challenge of Halal Industry}

The global halal product industry is not only surrounded by countries with a majority Muslim population such as Indonesia and Malaysia. Companies from China, Thailand, the Philippines, Britain and Luxembourg also competed to produce halal goods. Therefore it become the challenge of Europe to compe with other countries (Standard, 2015).

In recent years the halal trend has expanded even to America and Europe, especially the D-
A-CH countries consisting of Germany, Austria and Switzerland. D-A-CH itself is a term for a country that uses German as one of its main languages. Germany with a population of 82 million people, currently Muslims are ranked $3 \mathrm{rd}$, as many as 4 million people. Similarly, in Austria as many as 340,000 people and 310,800 for Switzerland. If added together there are around 4.6 million Muslims living in D-A-CH countries (Hussein Elasragh, 2018).

While the European Union has 16 million Muslim residents and around 54 million Muslims throughout Europe. Although not all Muslim populations consume halal products in the same way and not all obey strict religious regulations in consuming food. But the halal market has become so important because for non-Muslim consumers, the halal logo represents a symbol of cleanliness, quality, purity and safety. This symbol is the world standard and barometer that determines product quality. The halal market worldwide includes around 1.6 billion Muslim consumers with a sizable annual growth rate of around $1.84 \%$. Where the value is estimated at around 635 billion dollars or around 4 billion euros for Germany with the main products in the form of fresh meat and meat products. Unfortunately the increasing demand for halal products has not been fulfilled as a whole because of the lack of relevant halal certification institutions in the country that is fully recognized globally (Euromonitor, 2015).

Halal certification is a certification process for products or services according to Islamic sharia provisions. Halal certification was first performed in the United States in the 1960s as a guarantee for Muslims living in nonMuslim countries in order to meet the needs in accordance with the provisions of his 
religion. Halal is the requirements required for each product and service consumed by the people Islam, and is currently considered a product quality standard. Quality standard Halal is applied to the process of supplying and producing food, cosmetics, medicines and medical products and also applied to services related to halal products mentioned Noordin et al., 2014 in (Faqiatul Mariya Waharini, 2018).

In research (Rajagopal, 2011) that the halal certification of an item is seen as the best quality and hygienic product because of the strict rules and principles of this product it follows. In addition, companies attach halal certificates with their products and services to illustrate the safety and cleanliness of their products. Therefore, halal goods are producers' promises to consumers to provide quality, safe and clean products and services.

"When consumers buy products, they don't know if the products are halal, "haram" or "Shubhat." Food sold in non-Muslim countries can be considered a trust item as far as the halal concept is concerned. Halal certification system makes it possible to change trust items such as search items by including the halal certification logo on food packaging or food items themselves. Every Muslim individual is responsible for what he consumes. However, halal certification ensures that products produced are in accordance with Islamic law, but do not guarantee that after production, products are stored and transported according to Islamic law. The ingredients of products bearing the halal logo are stored in warehouses and transported appropriately, and pass through the production process in accordance with Islamic law. However, products with a halal $\log$ may be stored and transported improperly after production. For example, shelves and pallets for halal and non-halal products must be separated when transported" (Ngah, 2014).

"Halal food is physically similar to other foods, it has different nature, technique and method of processing slaughter. If animals have not been slaughtered according to prescribed Islamic rules, meat is not permitted for consumption. Products with halal support or certification are considered suitable for Muslims to consume. Certification symbolizes greater hygiene and nutrition. This is considered to have been produced under the supervision and strict requirements of Islamic law. Muslim consumers, especially in minority countries, will feel safe about purchasing these products without thinking about questioning their authenticity. Halal can also be seen as an indicator of quality even for non-Muslim consumers under the quality of a formal certification management system"(Mubbsher Munawar Khan, 2017).

This certainly becomes an obstacle for D-A$\mathrm{CH}$ countries in expanding the halal market to the entire world, especially the Middle East and Asia. The European Institute of Halal Certification (Germany) and Halal Certification Service (Switzerland) is the Halal institution in Europe. Furthermore, the increasing demand for halal certification, it becomes an agenda for D-A-CH countries to begin to be more serious in handling halal issues. Therefore, it is important for businesses to adopt halal certification for their food products and services for the development of their business (Javeed Anam, 2018).

The next challenge is the decline in halal products caused by Covid 19. The application of lockdown to suppress the spread of 
COVID-19, resulting in the supply of halal food products in Europe running low. One product that is now difficult to find by Muslims is halal meat because many halal meat traders are closed. Usually Muslims in Europe will choose to buy meat directly to a halal-labeled meat shop rather than in a supermarket because there is no guarantee that supermarket halal meat is 100 percent halal because it is stored and transported with non-halal products. Therefore, after the Covid 19 period is complete, support from various parties is needed to be able to improve the halal food industry in Europe.

\section{Conclusion}

Based on the results of research and discussion, Halal means justified. His opponent is forbidden to mean prohibited, or not justified according to Islamic law. While thoyyib means quality and does not endanger health. In Europe, The HFCE (Halal Food Council of Europe) has certified over 400 European food companies. This is expected to increase the growth of the halal food industry in Europe. The food industry in Europe is starting to see the potential for halal food as promising. As the dynamics within the Muslim world change and globalization trends continue to shape consumers' tastes, habit, and spending patterns across the world, the halal-based foods and beverages acceptance is poised to grow in Europe during the forecasted period. There is a great opportunity for European Muslims to position themselves favorably. Globally, more than 2.1 billion Muslims have the potential to network in the halal market, and they represent enormous spending power and economic potential. Meanwhile the challenge is the increasing demand for halal products has not been fulfilled as a whole because of the lack of relevant halal certification institutions in the country that is fully recognized globally. Therefore, the increasing demand for halal certification, it becomes an agenda for D-A$\mathrm{CH}$ countries to begin to be more serious in handling halal issues.

\section{Recommendation}

Based on the result of the research, discussion, and conclusion obtained in this study. The halal industry in Europe will develop quite rapidly. The Europe Halal Food and Beverages market is segmented, based on type, such that into halal foods, halal drinks, halal supplements. Moreover, the market, based on distribution channel, is segmented into hypermarket/supermarket, convenience stores, online channel and among others. Halal food products are not confined to meat and poultry, they also include other food items, such as confectionary, canned and frozen food, dairy produce, bakery products, organic food, beverages, and herbal products.

This food and beverage sector has great potential in the halal industry. Today's society is increasingly concerned with the halal food and drinks they buy. A publication by Geo Population in the Ministry of Trade's report that the Muslim population in France in 2011 reached 4.7 million people or 7.5 percent of the total population of the secular state. In France, within a period of 4 years, the average growth of the Muslim population reached 1.125 percent per year. Therefore the are many opportunities to increase halal food industry in Europe to meet the needs of Muslims. Besides that the increasing demand for halal certification is needed in handling 
halal issues. Then held various halal food festivals to increase the market potential of the halal industry in Europe.

\section{References}

A, A. (2016). An empirical study on nonMuslim's packaged halal food manufacturers: Saudi Arabian consumers' purchase intentionNo Title. Journal of Islamic Marketing, 7.

Al-Ghazali. (2007). Etika Islam Bimbigan Awal Menuju Hidayat Ilahi. Pustaka Setia.

Bolwijn, R., Casella, B., \& Zhan, J. (2018). International production and the digital economy. In Progress in International Business Research (Vol. 13, pp. 39-64). Emerald Group Publishing Ltd. https://doi.org/10.1108/S1745. 886220180000013003

Bonne, K., and Verbeke, W. (2018). Muslim consumer trust in halal meat status and control in Belgium. Https://Biblio.Ugent.Be/Publication?Q=par ent+exact+\%22MEAT+SCIENCE\%22.

Burhanudin. (2011). Hukum Perlindungan Konsumen. UIN Maliki Prees.

Euromonitor. (2015). Doing Business in the Halal Market-Products, Trends and Growth Opportunities.

Faqiatul Mariya Waharini, A. H. (2018). Model Pengembangan Industri Halal Food di Indonesia. Jurnal Muqtasid, 9.

Fauzi, M., Azizah, A. N., \& Nurfauziyah, L. (2020). The Concept of Ifta 'in Establishing Halal Law (Study of Usul fiqh on Legal Determination Methods). Journal of Digital Marketing and Halal Industry, $\quad 1(1), \quad 83$. https://doi.org/10.21580/jdmhi.2019.1. 1.4776

Halal la carte. (2020). The Economist.

Haleem, A. a. (2017). Towards successful adoption of halal logistics and its implications for the stakeholders. British Food Journal, 119.

Hussein Elasragh. (2018). 'Economics of Halal Industry. Kindle Edition.

Javeed Anam, B. M. (2018). Conceptualizing the relation between halal logo, perceived product quality and the role of consumer knowledge. Journal of Islamic Marketing.

Juan Eduardo Campo, ed. (2009). Halal. In Encyclopedia of Islam (p. 284). Infobase Publishing.

Lembaga Pengkajian Pangan, Obat-obatan, dan K. M. U. I. (LPPOM). (2016). DAFTAR Belanja Produk Halal, Daftar Produk Halal LPPOM.

Mubbsher Munawar Khan, H. A. (2017). Investigating the consumer behavior for halal endorsed products: Case of an emerging Muslim market. Journal of Islamic Marketing, 8(4), 625-641.

Mukhtar, A. a. (2012). Intention to choose Halal products: the role of religiosity. Journal of Islamic Marketing, 3, 108-120.

Ngah, A. Z. (2014). Adoption of halal Supply Chain among Malaysian halal Manufacturers: An Exploratory Study. Social and Behavioral Sciences, 129, 388395. 
Nur Asnawi, B. M. (2018). Halal Products Consumption in International Chain Restaurants among Global Moslem Consumers. International Journal of Emerging Markets, 132.

Pewforum. (2016). The Future of the Global Muslim Population. http://www.pewforum.org/ 2011/01/27/the-future-of-the-globalmuslimpopulation/ .Retrieved. 22 Desember 2019.

Rajagopal, S. R. (2011). Journal of Islamic Marketing. Halal Certifi Cation: Implication for Marketers in UAE, 2, 138153.

Rohman A. (2012). Pengembangan dan Analisis Produk Halal. Pustaka Pelajar.

Silalahi, U. (2010). Metode Penelitian Sosial. Refika Aditama.

Standard, T. R. and D. (2015). Global Halal Market. Halal Industry.

Suddin Lada, G. H. (2009). Predicting intention to choose halal products using theory of reasoned action. International Journal of Islamic and Middle Eastern Finance and Management, 2, 66-76.

Waqar Ahmed, A. H. (2018). Consumer behaviour towards willingness to pay for Halal products: An assessment of demand for Halal certifi cation in a Muslim country. British Food Journal. 
Journal of Digital Marketing And Halal Industry

Vol. 2, No. I (2020) 43-54 